\title{
Administrative Law Enforcement in Mining Businesses in Indonesia
}

\author{
Amelia Ayu Paramitha \\ Faculty of Law \\ Universitas Brawijaya \\ Malang, Indonesia \\ ameliaayu27@ub.ac.id
}

\author{
Tunggul Anshari Setia Negara \\ Faculty of Law \\ Universitas Brawijaya \\ Malang, Indonesia \\ tunggul@ub.ac.id
}

\begin{abstract}
The condition of administrative law enforcement in the environmental field is in fact still very concerning. The reality of this condition can be observed from various examples of violations regarding protected areas, sectoral permits that have not been utilized to control environmental impacts, careless waste disposal activities and weak law enforcement in the provision of administrative sanctions. Administrative sanctions are essentially regulated as the realization of environmental laws to guarantee the right of citizens to good and healthy environment as a basic right of every Indonesian citizen as mandated in Article $\mathbf{2 8 H}$ of the 1945 Constitution of the Republic of Indonesia

Indonesia is a country very rich in natural resources. The implementation of mining activities or the extraction of natural resources in Indonesian territory, therefore, requires permit aimed to protect them from total exploitation. The natural resources are divided into two, i.e. renewable resources and non-renewable resources. In terms of business licenses from the government, especially mining, the license is granted by the central and regional governments for mining business license holders, with predetermined mining areas covering the determination of mining areas, dassification of mining areas and criteria used in determining mining areas regulated in Law No. 4 of 2009 concerning Mineral and Coal Mining.
\end{abstract}

A mining business license (IUP) is a permit to carry out mining business in the framework of mineral exploitation that includes stages of general investigation, exploration, feasibility studies, construction, mining, processing and refining, transportation and sales activities, and post-mining activities. In the implementation of these mining activities, the permit holders do not always implement and comply with various laws and regulations. Of course, those who violate the provisions of the legislation are possibly subject to administrative and criminal sanctions.

This paper aims to analyze the administrative law enforcement in environmental field, especially in granting mining business licenses known to deal with a lot of abuse of authority, so that only a handful of people get the benefits. The disadvantaged people, on the other hand, are those who are affected by environmental damage caused by uncontrolled large-scale mining, which highlights the need of administrative law enforcement as a means of controlling.

Keywords—law enforcement, administration, mining business permit

\section{BACKGROUND}

The condition of administrative law enforcement in the environmental field is in fact still very concerning. The reality of this condition can be observed from various examples of violations regarding protected areas, sectoral permits that have not been utilized to control en vironmental impacts, careless waste disposal activities and weak law enforcement in the provision of administrative sanctions .

Administrative sanctions are essentially regulated as the realization of environmental laws to guarantee the right of citizens to good and healthy environment as a basic right of every Indonesian citizen as mandated in Article $28 \mathrm{H}$ of the 1945 Constitution of the Republic of Indonesia [1].

Being supported by good and healthy environment will guarantee the legal security for everyone and provide protection for the right of everyone to good and healthy environment as part of the protections to survive.

The law enforcement in adminis trative environ ment aims to stop unlawful actions or negligence that do not meet the requirements and return to the original state (before the violation)[2].

One of the environmental instruments related to admin istrative sanctions is an environmental permit, which refers to a permit granted to every person conducting a business and/or activity that is required by the Environmental Impact Analysis (amdal) or UKL-UPL in the context of environmental protection and management as a prerequisite for obtaining business and/or activity licenses, issued by ministers, governors, or regents/mayors in accordance with their authority. Article 40 of Law No. 32 of 2009 concerning the protection and management of the environment mentions that an environmental permit is a require ment for obtaining a business license and/or activity.

In practice, however, Officials with authority often violate the use of environmental permits. Currently, the environmental permit even overlooks business/activity. Local governments as the legal licensors are only motivated by shallow thought about issuing as many permits as possible to increase their regional revenue by marginalizing the as pect of environmental impacts .

Mining law is closely linked to environmental laws since every mining business, whether it is related to general mining and oil and natural gas mining, is required to maintain the perpetuity of the supporting capability and carrying capacity of the environment. This is commonly called as preservation environmental function (Article 1 point 5 UUPLH)[3]. 


\section{DISCUSSION}

One example of the administrative law enforcement in the environmental field is a legal effort aimed at preventing and overcoming environmental pollution and destruction through the use of administrative authority in accordance with the mandate given by the Constitution. Administrative law enforcement has several strategic benefits, namely:

- Administrative law enforcement in the environmental field can be optimized as a prevention device (preventive).

- Preventive administrative law enforcement can be more efficient in terms of financing, which includes the cost of field supervision that is carried out regularly.

- Administrative law enforcement has more capability of gaining community participation, which starts from the licensing process, monitoring of arrangement/supervision, and participation in filing complaints and imposing administrative sanctions.

Administrative law enforcement devices stemming from the law and the government should have initial terms of the effectiveness of administrative law enforcement in the environmental field which at least must include:

1. Permits, which are used as monitoring and controlling devices;

2. Requirements in the permit with reference to the Environmental Impact Analysis (amdal), environmental quality standards and legislation;

3. Existence of supervis ory officers (inspectors);

4. Monitoring and structuring mechanism; and

5. Adminis trative sanctions.

In admin istrative law enforcement efforts, there are several mechanism stages listed as follows:

1. Requests for permission (environmental permits or any permits related to environment) must be completed with environmental information as a decision-making tool. There is an Environmental Impact Analysis (amdal) study which includes several things: Environmental Management Plan (RKL) and Environ mental Monitoring Plan (RPL), Environmental Management Efforts (UKL) and Environmental Monitoring Efforts (UPL), and other related information;

2. Public consultation to obtain various inputs from the public before the permission is issued;

3. The existence of mechanism to facilitate public input aimed to avoid any lip services in public consultation;

4. Based on the submitted information, public input and decision making according to environmental feasibility, permission must include the requirements for prevention and mitigation of environmental impacts that are measurable, realistic and easily understood by permit holders and the society.

5. Permits that have been issued must be announced and are open to public.

6. Submis sion of the structuring status report must be is sued periodically by the permit holder and submitted to the regulator (main supervis or);

7. The inspection mechanism is carried out periodically according to the needs.
8. The rights and obligations of the supervisors, and the rights and obligations of the supervised objects have been guaranteed by the Law;

9. Administrative sanctions are applied systematically and gradually; and

10. There is a coordination mechanism between officials responsible for adminis trative law enforcement.

The Order of Administrative Sanctions in Admin is trative Law Enforcement is as follows:

a. Revocation

b. Permission

c. Suspension

d. Government coercion or recognizance

e. Mandatory Audit

f. Reprimand III

g. Reprimand II

h. Reprimand I

i. Technical Consultation \& Assistance for increased work

j. Voluntary Arrangement

All aspects of environmental law enforcement in Indonesia are very weak, including administrative law enforcement, most of which are caused by the following factors:

1. The absence of concepts, strategies and programs that are explained in utilizing administrative environment law enforcement;

2. The absence of concepts, strategies and programs that clearly influence the existence and readiness of human resources that implement and manage permits;

3. The licensing process is carried out privately between the regulator and the permit recipient that facilitates the misuse of the mandate and authority by the regulator; and

4. There is no determination and intention to utilize permits as a means of controlling environmental impacts.

To improve administrative law enforcement, various strategic steps are needed as follows:

1. Fixing inappropriate legislation; and

2. Simplifying the permits, both environmental permits and permits related to the protection of environmental functions, one of which is mining business license that includes general investigation, exploration, feasibility studies, construction, mining, processing and refining, transportation and sales activities, and post-mining activities.

\section{CONCLUSION}

Efforts to improve administrative law enforcement are very appropriate considering that currently there are many irregularities especially in granting mining business licenses that only benefit a few parties and harm the state in mining management, in post-mining activities, and the discovery of new minerals that are not included in the mining business license, resulting in detrimental mining activities to the state. Various mechanisms above are corrective measures that need to be studied further and integrated into the formation process and other relevant legis lative changes. 


\section{REFERENCES}

[1] Hamzah Andi, Environmental Law Enforcement, Sinar Grafika, Jakarta, 2005

[2] Peter Mahmud Marzuki, Legal Research, Prenada Media, Jakarta, 2005 .
[3] Rangkuti Siti Sundari, Environmental Law and National Environmental Policy, Airlangga University Press, $3{ }^{\text {rd }}$ Printing 2003 